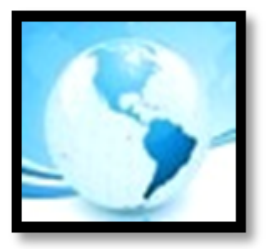

(MOJEM)

April 2020, VOLUME 8, ISSUE 2, 1 - 18

E-ISSN NO: $2289-4489$



\section{MEDIATING EFFECTS OF RELATIONSHIP QUALITY ON THE CORRELATIONS BETWEEN INSTRUCTIONAL LEADERSHIP AND LOYALTY}

Sarun Widtayakornbundit \& Boon-Anan Phinaitrup

\begin{abstract}
It is necessary that educational institutions are administered by leaders with visions who can be flexible while maintaining the institutions' missions. Instructional leadership will enable the leaders to manage effectively and to persuade teamwork to be fully engaged in dynamic educational contexts. The purpose of this study is to explore the effectiveness of instructional leadership as an independent variable to instructors' behavior. This relates to employees' loyalty to their leaders and institutions through the relationship quality as a mediator variable which is considered as a direct effect from instructional leadership. The research's respondents were instructors who worked under the dual system of private vocational education institution in Thailand and the sample data was collected from 396 instructors. The result showed that almost variables has a direct impact to each other except trust in the relationship quality group. This variable has no effect on job satisfaction and institution loyalty $(p<$ 0.05). The model explained that 60.9 percent of leader loyalty and 59.7 percent of institution loyalty were variation of instructional leadership. The finding clearly reveal the instructional leadership helps to estimate what can contribute to the relationship quality and the loyalty in educational institution. The study recommends that the board of management with instructional leadership should examine the personnel's needs to maximize institutional personnel in a more professionally manner.
\end{abstract}

Keywords: Dual System, Instructional Leadership, Loyalty, Relationship Quality, Vocational Education 


\section{MALAYSIAN ONLINE JOURNAL OF EDUCATIONAL MANAGEMENT (MOJEM)}

\section{INTRODUCTION}

Educational guidelines of the dual system that have been applied to Thailand's vocational education system were focused on the collaborations between academic institutions and business organizations or private sectors. The government sector control the guidelines of such collaborations. For the guidelines, Dual Vocational Education Center (DVEC) under the Vocational Education Commission, Ministry of Education was involved in developing the standard qualifications framework to align with the national economic and social development plan as well as the national education plan. Previously, Thailand's vocational education geared towards equipping and producing its graduates for economic fluctuation. The Thai workforce will need to adjust itself to such dramatic fluctuation and to dynamic of industrial sector. Development of the Thai labor, thus, is not the concern only for the quantity of the labor but also its qualities. Such qualities could include specific job competency, adaptability of qualified workers, and internationally-ready trained labor.

Vocational education is learners' educational alternative. This may be because some groups of students are not familiar with high school educational system or are in need to enter the workforce earlier than the other groups of students do. For this reason, vocational education could offer opportunities for learners to further their careers while being able to properly maintain their educations. Vocational education system allows its learners to gain a more customized education. This clearly reflects the democracy of individual learners and paves the way for learners to do what suits them the most.

The appropriation of vocational education guidelines together with those of dual system of vocational education allows learners to fully involve in interdisciplinary studies and be ready to enter the workforce more efficiently. The advantage of such appropriation reflects through the quality of learners. The learners are able to exhibit clear understanding of in-class-content because of the in-class instructions and hand-on experiences from real-life classes occurred in organizations. The organizations allow the learners to gain practices that will receive some benefits from the learners. The organizations would not have to offer training sessions to the learners which allow the companies to save cost. The learners' academic institutions will also gain some advantages. The learners will usually bring back their new knowledge or problems they have experienced from the assigned tasks in the organizations. Such knowledge and problems allow the institutions to form new set of theoretical knowledge or some new approaches in order to improve the institutions' programs to meet the demands of the real world. It could be said that such appropriation brings benefits to all stakeholders.

The appropriateness of managing both personnel's behaviors and the dual system of vocational education in vocational institutions links to the key issue of leadership. An effective leader of a vocational institution must be able to see the big picture of the whole institution as well as the smaller but significant just like personnel management. For the continuous growth of the institution, the leader must allow both to collaborate. Since the management of the dual system of vocational education in vocational institutions has recently been implemented, many significant changes through the management system may affect institutional stakeholders. Such stakeholders include those individuals and groups who design the old programs as well as the new interdisciplinary programs to pave the guidelines for people involved to accept and follow. The effective leader who could manage as such is considered as being involved in challenges of instructional leadership.

\section{LITERATURE REVIEW}

\section{Instructional leadership}

Instructional leadership refers to educational institution management towards learners' success. Such management involves strong commitment from institutional personnel (Klar, 2012; Ng, Nguyen, Wong, \& Choy, 2015), either the members of the board or instructors(Hulpia, Devos, \& Van Keer, 2009). The significance of having the so-called instructional leadership is at the proper management of relationships between instructors and 


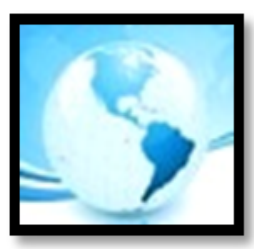

\section{MALAYSIAN ONLINE JOURNAL OF EDUCATIONAL MANAGEMENT (MOJEM)}

leaders or the board members. The instructors should understand institutional missions and objectives or other institutional needs while being able to manage appropriate classrooms based on learners' abilities. The board members should give full support to the instructors and the learners. It is in order to allow the institutional missions and objectives to be met (Hulpia, Devos, Rosseel, \& Vlerick, 2012).

The responsibilities of the instructional leaders lie in providing supports to institutional personnel, managing and implementing institutional policies as well as strategic plans (Leithwood, 2016). It could be said that instructional leadership is not only to defend his or her ground, but also to proactively involve in every dimension in institutions as investigators. Such investigators will need to assess the programs whether they are offering expected outcomes and to examine learners' feedbacks (Ilgan, Parylo, \& Sungu, 2015). The responsibilities of the instructional leaders draw on their understanding of people who are under them. They should not force their people to do the assigned tasks. Instead, the instructional leaders should bend the institutional rules to leave more room in supporting their personnel to work to their full capacity and in allowing learners to achieve their customized academic goals.

The variables in this study was derived from the development of instructional leader's characteristics in which Hallinger and Murphy (1985) laid the foundation, Murphy (1990), and Smith and Piele (1997) offered the definition of instructional leader's characteristics. The meaning of instructional leader is capabilities to nurturing educational institutions, programs, and personnel to be able to benefit learners and take social responsibilities. In this research work, instructional leader's characteristic framework of Alig-Mielcarek and Hoy (2005) was employed. This was to measure the findings according to the theoretical concepts of individual goal setting and work motivation from leaders. These concepts involve: 1 ) defining and communicating goals allowing every staff to thoroughly understand organizational goals and reasons behind them through interactive communication process. It is to say that the process starts from leaders to followers while the leaders also acknowledge the followers' needs in order to work successfully for the organizations; 2) monitoring and providing feedback on teaching and learning process is the working process from the beginning for a duration of time or when the work has been accomplished. Leaders must investigate instructional or learners' problems or assess the results of the work. This is to gain a better management; 3) promotes school-wide professional development that urging or persuading personnel in career advancement. Leaders are to select appropriate personnel in such advancement process or to have their followers developed their professional qualities. In addition, leaders are to support to their followers to allow them to work successfully while being able to develop their work qualities.

\section{Relationship Quality}

The concept of 'Relationship Quality' focuses on related or affected behaviors in specific contexts which the leaders and the supporters exhibit (Kuhn \& Mostert, 2018). An example of educational context involves the work of Perkins (1965). Perkins (1965) stressed that leaders' plans and performances affect the lesson plans of instructors. The instructors usually set their plans to respond to the needs of their educational institutions based on their awareness of the leaders' performances. In the same vein, Hong (2017) stated that leaders, who wish to see instructors' teaching performances that are strongly based on the organizational cultures, exchanged knowledge from students, and trust from parents of those students, should take the relationships between the leaders and the instructors seriously to satisfactory level. The explanation of this statement could be explained by social exchange theory where the reactions of the supporters will dynamically change in response to the relationships between the leaders and the supporters in specific contexts (Ndubisi, Malhotra, Ulas, \& Ndubisi, 2012).

In this study, the selection of the dimensions of Relationship Quality was based on literature reviews. The related articles and the variables in this research work have been selected because the articles have been cited or the variables have been chosen to apply to educational leadership and educational management works as well as to fit with the universal model that are reliable since it has been proven by findings of many research studies. The drawback in the selections would be that they lacked of context specificity (Y. Lee, 2016). When applied the 


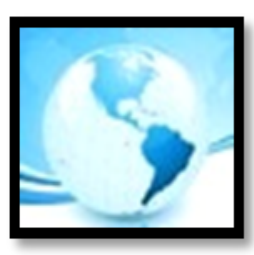

\section{MALAYSIAN ONLINE JOURNAL OF EDUCATIONAL MANAGEMENT (MOJEM)}

selections, many questions and variables needed to be adjusted to suit the context of the study. In this research work, trust, organizational commitment, job satisfaction, and loyalty have been chosen to be examined. The variables in these issues affected the behavioral relationships. The explanations of each variable are as follows.

\section{Trust}

Trust refers to the expectations of leaders and supporters' behaviors which pave the way to benefits for each party. Although such benefits could be shared equally or unequally, trust is based more on each party's satisfaction according to what have been settled between the two parties (Robinson, 1996; Zhu \& Akhtar, 2014). There are several kinds of trust. Thus, it is up to the leaders to select and apply trust to their organizations (Kramer \& Tyler, 1996). To one extent, it could be a risk to base the management on trust. When the members of the organizations understand the process and other related issues involving in the management, it is worth a try.

Northfield (2014) explained the concept of trust which has been applied in organizations. The development of trust in organizations or between the board and the personnel in educational institutions starts from role trust. Everyone in the organizations usually follow role patterns and observe if those people in such role patterns behave as expected, or it is known as practice trust. The responses from this practice trust will lead to the conclusion of what is beneficial and what is not in order to allow behavioral changes to happen in the organizations. When the board of any educational institutions applies and implements the conclusion based on the practice trust, it is called integrative trust. This kind of trust leads to the final stage of trust known as correlative trust. Correlative trust refers to the adjusted relationships based on the values the educational organizations given to subordinates or the board when the levels of trust have been positively geared towards. Along the same line as in the study of Gregory (2017), good leaders are those who pay particular attentions to cultures of educational institutions in order to give full supports to work behaviors and maintain positive relationships among people in the institutions. These attentions are based on trust between the leaders and the supporters.

\section{Organizational commitment}

Organizational commitment involves the mapping of personal values of the personnel to the organizational values (Buchanan, 1974). Cohen (2007) addressed that the more positive level of organizational commitment the personnel has, the better relationships between the personnel and the organization could be maintained. Later, the organization could motivate the personnel to work for it and could turn the personnel's negative attitudes towards the organization to the positive ones. In order to do this latter stage, leaders should also focus on the categorizations of emotions and feelings of the personnel. This is for the leaders to properly manage the organization. It is clear that the organizational commitment is significant for any organizations. Thus, its concept has been continuously developed and applied. The overall concept is to allow the subordinates to realize their relationships with the organizations and the customizations in management that lead to organizational commitment. This kind of commitment will, of course differ from one organization to another. It is to say that organizational commitment is unique for each organization and differ in the way in which one organization motivates its personnel to make commitment to work for it.

In the context of educational institutions, organizational commitment could be seen through dedication to work, taking full work responsibilities, and work effectiveness of each personnel in each semester (Hulpia et al., 2012). Or it could be viewed through the numbers of years the personnel have worked the institutions. When all of these have been evident, it is clear that the institution is successful in building up and maintaining organizational commitment of its personnel (Ennis, Gong, \& Okpozo, 2018). This evidence would in turn reflect the learners' educational outcomes(Pietsch \& Tulowitzki, 2017). It is to say that without organizational commitment, it is impossible to create work motivation. Therefore, educational institutions should be aware of this issue and attempt to apply the concept with the board's managerial procedures and processes. This is to nurture sustainability in the organizations. 


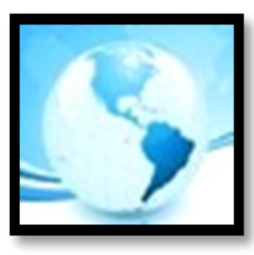

MALAYSIAN ONLINE JOURNAL OF

EDUCATIONAL MANAGEMENT

(MOJEM)

Job satisfaction

Job satisfaction involves individuals' work experiences which relate to how individuals emotionally handle their job responsibilities (Aldas-Manzano, Ruiz-Mafe, Sanz-Blas, \& Lassala-Navarré, 2011). This is considered as a supplement factor towards a good work quality. Job satisfaction is related to the work design and prioritization of the individuals in charge which could usually be observed through employee feedbacks and incentives from employers or organizations(Noe, Hollenbeck, Gerhart, \& Wright, 2014). Rojas-Méndez, Vasquez-Parraga, Kara, and Cerda-Urrutia (2009) discussed about the job satisfaction in their research. They highlight the importance of job satisfaction that lies in the assessment of employee feedbacks. The organizations must take the feedbacks seriously and design the work itself or set the proper work environment for the employees to be able to continually work for them.

Satisfaction and unsatisfaction is the two sides of the same coin. On one side, the individuals work on the same things and receive experience of job satisfaction while another could feel the latter (Sayadi, 2016). Thus, the first individual may present a good quality of work whereas the other one submit his or her work of bad quality. Shen, Leslie, Spybrook, and Ma (2012) explained that job satisfaction affects school management process. Employee emotions or feelings are strongly related to their work qualities. It is to say that the employee motivation to work is impacted by the board, the employees, and the learners. The board of educational institutions should improve the qualities of work environment or provide full support to maximize the positive work experiences of employees. Building up the satisfaction towards the work itself could lead to positive outcomes in allowing the employees to work for the companies longer. Apart from the quality of the work itself that allows the employees to feel satisfied for their jobs, the inner satisfaction of the employees towards the organizations should also be maintained (Thobega \& Miller, 2003).

\section{Loyalty}

Loyalty refers to filling in the expectation of each party's relationship which each party sets based on personal attitudes (Hart \& Thompson, 2007). Loyalty is the psychological signal that human beings exhibit when being affected by other types of behaviors. It is because the foundation of loyalty is based on multiple forms of behaviors. These behaviors lay the communication ground for human beings to interact (Kont \& Jantson, 2014). In related literatures, organization loyalty has been obtained great attention from members in organization. It is because this kind of loyalty could be related and applied to many contexts. Chaudhuri and Holbrook (2001) stated that loyalty has a great deal of effect towards trust more than other kinds of behaviors. Loyalty is based on continuously positive relationships (Foster, Whysall, \& Harris, 2008). Building up loyalty, thus, depends on the organizations to nurture proper basic workplace behaviors which gear toward a more effective human and organizational management.

In this study, loyalty is divided into two parts. The first part relates to educational loyalty and attitudinal loyalty. The educational loyalty helps create behavioral loyalty among employees to allow them to behave in a more positive light towards organizations. When the employees create behavioral loyalty, it is usually from what know as attitudinal loyalty. It refers to the feelings from inside of the employees to behave positively towards the organizations (Ting \& Yeh, 2014). The second part is loyalty towards the educational board. This kind of loyalty is adjusted from two types of loyalty: affected-based loyalty and role-based loyalty. The affected-based loyalty relates to emotions and feelings of employees towards employers as well as to whether or not the employees will support the employers' works. The role-based loyalty focuses on the commitment of the employees towards their job responsibilities. The overall picture of these two types of loyalty is similar. It is to say that the affection and the attitudes of the employees towards the employers come from the social exchanges as interactants and as prescribed by work positions. Thus, loyalty is related to emotional development in many dimensions to fit with contexts that each individual has experienced. 
The framework of this research study was to present the roles of educational leadership which affect loyalty (Figure 1). The variable acted as the mediator is relationship quality. The structural equation model was employed in this study to statistical relationships by taking into account of private vocational education institutions across Thailand in which they apply the dual system to their institutional systems.

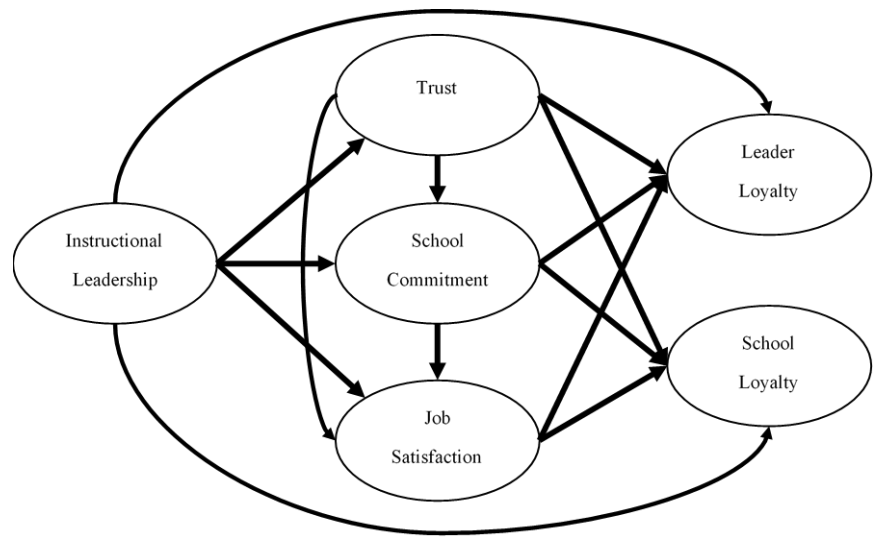

Figure 1. Conceptual Framework

Instructional leadership is considered as the important variable in designing behaviors. It is because Instructional leadership allows individual personnel management to work together with institutional program management. Instructional leadership is deemed to have a great deal of impact towards the work effectiveness which leads to organizational loyalty and later the learners' academic success (Klar, 2012; Pietsch \& Tulowitzki, 2017). Instructional leadership also affects emotional conditions which stem from communications between the leaders and the supporters (Lesinger, Dagli, Gazi, Yusoff, \& Aksal, 2016). Such communications create trust, work motivations, and later job satisfaction (Dutta \& Sahney, 2016). Thus, instructional leadership is salient since it has its ground from interdisciplinary of manpower and the work itself. When they are interwoven, it leads to cooperative and dedication of the employees for the leaders and education institutions. This is all about the relationship between Instructional leadership and loyalty (Hulpia et al., 2009).

The relationship quality group behavior reflects the voluntary of personnel's work commitment in organizations. This relationship quality has clearly shown its relationships with other variables at other levels of analyses, which lead to a more positive behavior personnel would exhibit towards the leaders and the organizations. With such a strong work commitment(Chaudhuri \& Holbrook, 2001; Dorenkamp \& Ruhle, 2018), the personnel would develop their trust and their loyalty towards organizations or organizational loyalty (Lee \& Fenich, 2018; Perin, Sampaio, \& Brei, 2007). The work commitment, trust, and organizational loyalty could be viewed as related to one another. To prolong all of these, it depends on a more careful design of work that focuses on individual performances. To bring out positive individual performances, any forms of support from the leaders or organizations are needed for the employees to feel positive towards the leaders and organizations. In turn, this enables good work qualities and positive relationship maintenance in all levels of the organizations (Hoyt, 2012; Rojas-Méndez et al., 2009). Nonetheless, this study focuses only on the behaviors of the personnel in the recent dual system of private vocational education system in Thailand and may not be able to be generalized to other groups of people' $s$ behaviors.

Based on the concepts and reviews of literature mentioned above, the use of variables ISL, RQ, and Loyalty is considered as the framework of the study which also helps to explain the behaviors of the personnel in this research work as shown in Figure 2 below. 


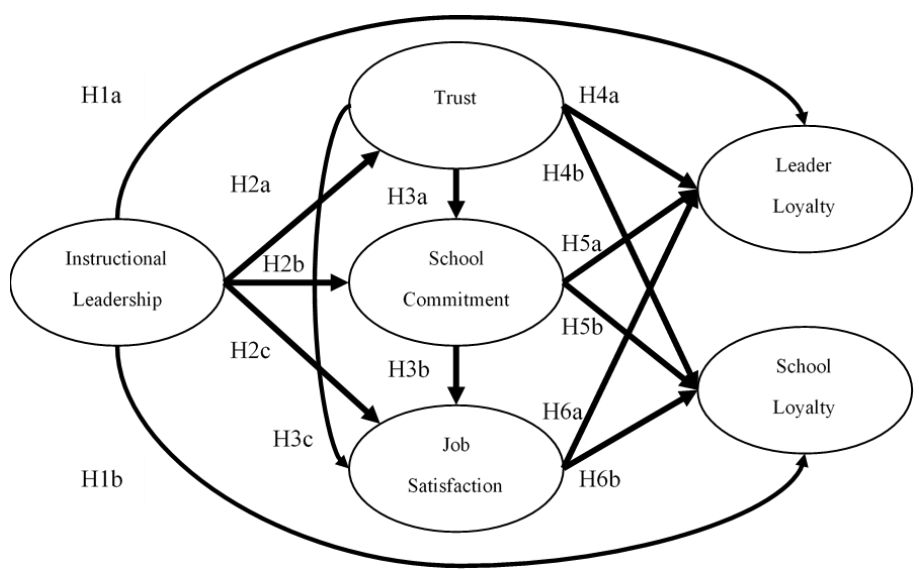

Figure 2. Research Design

In this research framework, it shows the relationships between variables which derive the research hypothesis between variables as follows:

H1: Instructional leadership impacts the acts or behaviors which reflect loyalty towards the board of management (H1a) and educational institutions (H1b).

$\mathrm{H} 2$ : Instructional leadership impacts the relationship quality group such as; trust (H2a), school commitment (H2b), and job satisfaction $(\mathrm{H} 2 \mathrm{C})$ of the personnel in educational institutions.

H3: The relationship quality behavior group affects the act or behavior each other such as trust impacts school commitment ( $\mathrm{H} 3 \mathrm{a})$, school commitment impact job satisfaction ( $\mathrm{H} 3 \mathrm{~b})$, and trust impact to job satisfaction (H3c)

H4: Trust affects the acts or behaviors which reflect loyalty towards the board of management (H4a) and educational institutions (H4b).

H5: School commitment affects the acts or behaviors which reflect loyalty towards the board of management (H5a) and educational institutions (H5b).

H6: Job satisfaction affects the acts or behaviors which reflect loyalty towards the board of management ( $\mathrm{H6a}$ ) and educational institutions (H6b).

\section{RESEARCH METHOD}

\section{Research design}

The survey research was used to seek the relationships among independent variables. The independent variable was instructional leadership which had relationship quality (organizational commitment, trust, and job satisfaction) as mediator variable, and loyalty as dependent variable. The analysis unit was the personnel who worked under private vocational education institutions across Thailand in which they applied the dual system to their institutional systems. This survey research was completed in cross section. The hypotheses of the study were tested using the scores from the survey which were based on Likert scale. Then, the structural equation model method (SEM) was used to calculate statistical relationships and to lead to the confirmatory factor analysis (CFA). This was to seek factor loading value. This quantitative result was then used to adjust the variables to suit the 


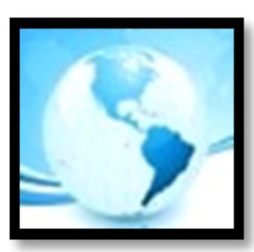

\section{MALAYSIAN ONLINE JOURNAL OF EDUCATIONAL MANAGEMENT (MOJEM)}

study. In addition, the relationships between variables through multiple regression and path analysis had been taken into consideration.

\section{Population \& Sampling}

The research population included 428 private vocational education institutions across Thailand where they have applied the dual system to their institutional systems. The sample of population method employed was according to simple random sampling. Afterwards, the method of purposive sampling was used to collect the data. The sample of the population includes academic employees in the dual system, deputy administrators, and vice heads of the department. Questionnaires were handed to employees at the community enterprises focussed in this study. To scope the sample group, the following DVEC selection criteria were applied. The DVEC criteria included instructor criteria which qualified by Thailand professional qualification, professional development course more than forty hours/semester, and arrange training course in educational institution for two hours/semester. The firm agreement with educational institute was included in DVEC regulation such as; knowledge appraisal course for coaching in enterprises, profession training more than 30 hours/year, and trainer experience in corporate more than 6 months.

Then, the informants were limited even more when the sample group went through other qualification. The respondents in this study must be in the institutions where have been applied the dual system for at least one year, and have been certified by the Ministry of Labor. These informants must have experienced the dual system program at least one year. Another qualification of respondents would be those who graduated with a bachelor degree and possessed official teaching permits issued by the teachers' council of Thailand. When the qualifications above were set, the sample group was down to 131 institutions. The analysis required six latent variables and the sample groups of 60 to 120, which the maximum of data should exceed 200 sample groups. The appropriate number of samples, therefore must be more than 200 samples because the parameter estimation also uses the method of maximum likelihood (Lindeman, Merenda, \& Gold, 1980). Such method was used for multivariate analysis. The number of the informants whom responded in the questionnaires was then left to 396 . This sample size is confine for applying to use in the structural equation model analysis.

\section{Research Instrument}

The questionnaire was the main research instrument of this study. The selection of the operational variables in the questionnaire were derived from related literatures. The operational variables were tested for their validity and reliability. The questionnaire used Likert scale, ranging from (1) to (5) in which (1) referred to absolutely disagree and (5) referred to extremely agree. All parts of the questionnaire were taken from English literature review that would be translated into Thai or applied into the dual system in Thailand contexts. Later, the questionnaire would be translated back into English (Brislin, 1980). The questionnaire was divided into parts which were based on variable measurements. Instructional leadership section was measured and applied from the Instructional Leadership Inventory questionnaire of Alig-Mielcarek and Hoy (2005) at twenty-three items. For the relationship quality measurement, this study presents three constructs of mediator: 1) organizational commitment, adapted from commitment scale of Angle and Perry (1981) at ten items; 2) trust which applied from the trust scale of Robinson (1996) at four items; 3) job satisfaction which was adapted from job descriptive index )Houtte, 2006; Vaughn \& Dunn, 1974) at ten items. The dependent variable in the issue of loyalty which was divided into leaders loyalty, adapted from loyalty measurement of Jiang and Cheng (2008) at eight items; and school loyalty which was modified from teacher loyalty scale by Ting and Yeh (2014) at four items. The total number of the questionnaire derived from the reliability measurement and the factor loading analysis with confirmatory analysis method (CFA). 


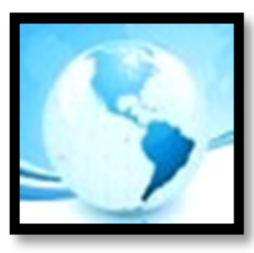

\section{FINDINGS AND RESULT}

\section{Demographic Information of responded the questionnaire:}

The sample group included more females than males at 60.1 percent, 68.9 percent of the sample group graduated with the bachelor degrees. The majority of academic position group working as instructor was at 78.8 percent of the sample group. Most of seniority in academic (41.7 percent) had been working for the institutions from one to five years. The 47.7 percent of respondents were in their tenure tracks from one to five years. The criteria in justifying the sample group's duration of work and tenure treacle were based on the official job requirements of personnel who worked in the dual system. Although the majority of the sample group belonged to the instructors, the rest of the sample group was comprised of administrative staff and leaders of departments or programs. The information is shown in Table 1 as follows:

Table 1

The Demographic Information of Respondents

\begin{tabular}{|c|c|c|}
\hline Status & Number & Percentage \\
\hline \multicolumn{3}{|l|}{ Gender } \\
\hline Male & 153 & 39.9 \\
\hline Female & 238 & 60.1 \\
\hline \multicolumn{3}{|l|}{ Education level } \\
\hline Bachelor degree & 273 & 68.9 \\
\hline Master degree & 117 & 29.5 \\
\hline Doctoral and other & 6 & 1.6 \\
\hline \multicolumn{3}{|l|}{ Academic Position } \\
\hline Instructor / Teacher & 312 & 78.8 \\
\hline Supervisor / Director & 34 & 8.6 \\
\hline Operation and Other & 50 & 12.6 \\
\hline \multicolumn{3}{|c|}{ Seniority in Academic (year) } \\
\hline $1-5$ & 165 & 41.7 \\
\hline $6-10$ & 90 & 22.7 \\
\hline $11-15$ & 43 & 10.9 \\
\hline $16-20$ & 26 & 6.6 \\
\hline 21 and over & 72 & 18.2 \\
\hline \multicolumn{3}{|c|}{ Tenure in current position (year) } \\
\hline $1-5$ & 189 & 47.7 \\
\hline $6-10$ & 95 & 24.0 \\
\hline $11-15$ & 37 & 9.3 \\
\hline $16-20$ & 21 & 5.3 \\
\hline 21 and over & 54 & 13.6 \\
\hline
\end{tabular}

\section{Measurement Weighting Factor}

The research was based on calculation of the factor loading which was analyzed by confirmatory factor analysis. The significance of each variable would not be lower than 0.5 based on the criteria of Hair, Black, Babin, and Anderson (2009). The reliability test would be at 0.70 (or in some circumstances 0.60 was possible to accept), this is referenced by Nunnally (1967). The figure shows the internal correlation between latent variable which reflects instructional leadership as its endogenous latent variable. The measurement of this correlation came from value weighting factor which derived from standardized regression weight of the following variables (1) promotes 


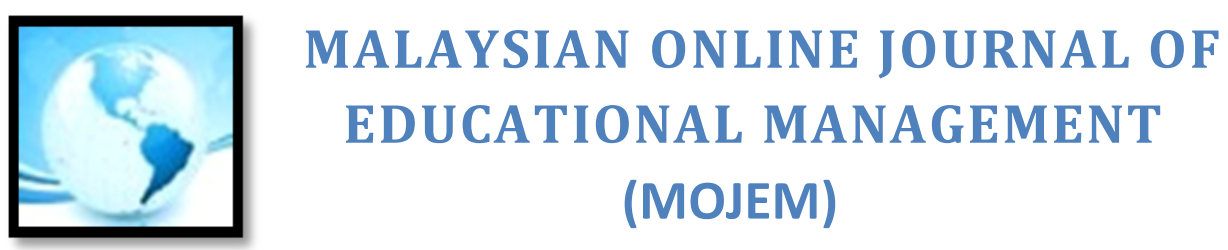

school-wide professional development (weighting factor value at 0.86), (2(defining and communicating goals (weighting factor value at 0.86), and (3) monitoring and providing feedback on teaching and learning process (weighting factor value at 0.87). The findings from other indexes involved organizational commitment, trust, and job satisfaction of the group of relationship quality and loyalty. All of these were shown in Figure 3 and Table 2.

Table 2

The Reliability testing.

\begin{tabular}{|c|c|c|c|c|}
\hline Variable & Item & Mean & S.D. & Cronbach alpha \\
\hline \multirow[t]{3}{*}{ Instructional Leadership } & $\begin{array}{l}\text { Promote school-wide professional } \\
\text { development }\end{array}$ & 4.19 & 0.54 & 0.687 \\
\hline & $\begin{array}{l}\text { Defines and communicates shared } \\
\text { goals }\end{array}$ & 4.24 & 0.49 & 0.804 \\
\hline & $\begin{array}{l}\text { Monitors and provides feedback } \\
\text { on the teaching and learning } \\
\text { process }\end{array}$ & 4.23 & 0.49 & 0.800 \\
\hline Relationship & Trust & 4.13 & 0.63 & 0.861 \\
\hline \multirow[t]{2}{*}{ Quality } & Commitment & 4.24 & 0.48 & 0.872 \\
\hline & Job Satisfaction & 4.26 & 0.52 & 0.903 \\
\hline \multirow[t]{2}{*}{ Loyalty } & Leader Loyalty & 4.18 & 0.54 & 0.906 \\
\hline & School Loyalty & 4.31 & 0.60 & 0.910 \\
\hline
\end{tabular}

The results from the structural equation modeling or SEM analysis have shown that CMIN (chi-square) $=29.697, \mathrm{df}$ $=10, \mathrm{CMIN} / \mathrm{df}=2.970, \mathrm{GFI}=.982, \mathrm{CFI}=.991, \mathrm{TLI}=.974 \mathrm{RMR}=.005, \mathrm{RMSEA}=.071$, and HOELTER $.05=244$. The overall picture was additively confirmed. It means that the SEM used in research work has fit well for the model and according to the standard measurement.

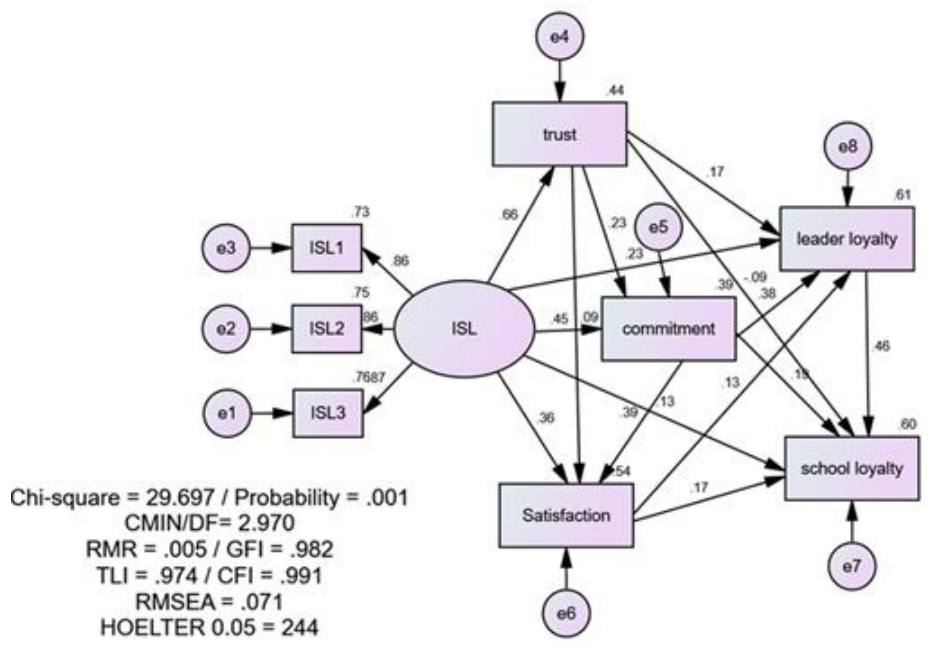

Figure 3. Verification Test Result

The results of the estimated value from the square multiple correlation exhibited the instructional leadership model which affected leader loyalty at 0.609 or 60.9 percent and school loyalty at 0.597 or 59.7 percent. The results allow the possibility of applying the model for loyalty justification. The results also highlighted the greater 


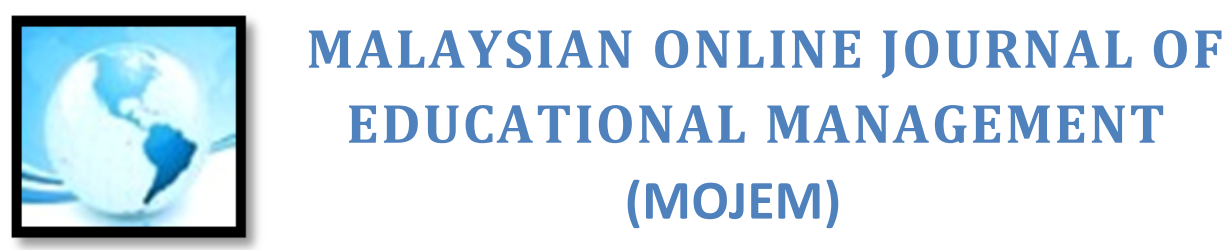

effect of the leader loyalty than that of the school loyalty. For other correlations of other variables, Instructional leadership may have an effect on trust at 0.661 or 66.1 percent. Instructional leadership also impacted organizational commitment at 0.42 or 45.2 percent while affected job satisfaction at 0.36 or 0.36 percent.

The results are illustrated in the model and table 3 that only employs instructional leadership in a private vocational institution with dual system, the causal relationships among each variable will be obvious. According to figure 3, there are some variables that do not have relationship with others variables. Trust has no impact on job satisfaction and loyalty towards the institute.

Table 3

Explained Variance: Instructional leadership

\begin{tabular}{|c|c|c|c|c|}
\hline & \multicolumn{4}{|c|}{ regression weight } \\
\hline & Estimate & S.E. & C.R. & P-value \\
\hline \multicolumn{5}{|l|}{ Instructional leadership } \\
\hline Trust & 0.977 & 0.067 & 14.662 & $* * *$ \\
\hline Commitment & 0.501 & 0.066 & 7.551 & $* * *$ \\
\hline Job satisfaction & 0.437 & 0.069 & 6.316 & $* * *$ \\
\hline Leader loyalty & 0.288 & 0.07 & 4.105 & $* * *$ \\
\hline School loyalty & 0.176 & 0.081 & 2.179 & $0.029 * *$ \\
\hline \multicolumn{5}{|l|}{ Trust $\left(R^{2}=0.438\right)$} \\
\hline Commitment & 0.171 & 0.042 & 4.079 & $* * *$ \\
\hline Job satisfaction & 0.071 & 0.04 & 1.787 & 0.074 \\
\hline Leader loyalty & 0.147 & 0.038 & 3.869 & $* * *$ \\
\hline School loyalty & -0.084 & 0.043 & -1.957 & 0.050 \\
\hline \multicolumn{5}{|l|}{ Commitment $\left(R^{2}=0.392\right)$} \\
\hline Job satisfaction & 0.43 & 0.049 & 8.692 & $* * *$ \\
\hline Leader loyalty & 0.436 & 0.051 & 8.547 & $* * *$ \\
\hline School loyalty & 0.236 & 0.062 & 3.806 & $* * *$ \\
\hline \multicolumn{5}{|l|}{ Job satisfaction $\left(R^{2}=0.542\right)$} \\
\hline Leader loyalty & 0.14 & 0.049 & 2.832 & $0.005^{* *}$ \\
\hline School loyalty & 0.197 & 0.056 & 3.528 & $* * *$ \\
\hline \multicolumn{5}{|l|}{ Leader loyalty $\left(R^{2}=0.609\right)$} \\
\hline School loyalty $\left(R^{2}=0.597\right)$ & 0.509 & 0.057 & 8.902 & $* * *$ \\
\hline
\end{tabular}

$* \mathrm{p}<.05, * * \mathrm{p}<.01, * * * \mathrm{p}<.001$

The total effect of instructional leadership on the group of relationship quality has included: organizational commitment is calculated as total effect at .603; trust is calculated as total effect at .611; and job satisfaction is calculated as total effect at .656. For the dependent variables in the group of loyalty, it involved leader with its total effect at .663 and school loyalty with its total effect at .597. The total effect of each variable in the group of relationship quality to others included trust on the organizational commitment with its total effect at .227; job satisfaction with its total effect at .284; leader loyalty with its total effect at .284; and school loyalty with its total effect at .114. For the others in the group of relationship quality group, organizational commitment involved job satisfaction at .394; leader loyalty with its total effect at .437; and organization loyalty with its total effect at .455. 


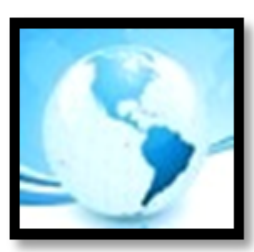

The total effect of job satisfaction on leader loyalty at .135 and school loyalty with its total effect at .233 . The total effect on the loyalty group also has effects to each other at 0.459 . The result of these were shown in table 4.

Table 4

Statistic Total Effect Test Results.

\begin{tabular}{lccccc}
\hline & ISL & trust & commitment & job satisfaction & leader loyalty \\
\hline trust & 0.611 & - & - & - & - \\
commitment & 0.603 & 0.227 & - & - & - \\
job satisfaction & 0.656 & 0.284 & 0.394 & - & - \\
leader loyalty & 0.663 & 0.284 & 0.437 & 0.135 & - \\
school loyalty & 0.597 & 0.114 & 0.445 & 0.233 & 0.459 \\
\hline
\end{tabular}

The conclusion of hypothesis testing on instructional leadership is rejected two hypotheses from instructional leadership model. The hypothesis in $\mathrm{H} 3 \mathrm{C}$ is shown in Table 3 and shows that there is no significance on job satisfaction $(p<.05)$. There is not a relationship between trust and educational institutions which denied the hypothesis in $\mathrm{H} 4 \mathrm{~b}(\mathrm{p}<.05)$. The findings evidenced the significant statistic for the hypothesis $\mathrm{H} 1$ and $\mathrm{H} 2$ that instructional leadership helps estimate which can contribute loyalty to the board of management and educational institutions. The results also confirmed the direct effect between trust and school commitment (H3a), school commitment and job satisfaction $(\mathrm{H} 3 \mathrm{~b})$. The term of relationship quality variable was influenced to the group loyalty. The resulted support the hypothesis $\mathrm{H} 4 \mathrm{a}, \mathrm{H} 5 \mathrm{a}, \mathrm{H} 5 \mathrm{~b}, \mathrm{H} 6 \mathrm{a}$ and $\mathrm{H} 6 \mathrm{~b}$ that have directed effect to the loyalty.

The findings of the study show that instructional leadership affects behaviors of personnel in educational institutions in lights of relationship quality and loyalty. This type of leadership could be considered as the standard of educational institution management. It is because such leadership helps create proper management structure of educational institutions together with professional readiness of the personnel. At the bottom line, this type of leadership allows the learners to reach their academic outcomes more successfully. Hallinger and Murphy (1985) explained about attempts of the board in implementing management strategies to align with visions of both the institutions and the personnel. The management will not be for one group's benefit, but for all. In the same vein, Leithwood (2016) focused on the development of educational institutions which is based on human resources. The institutions must have their program assessments and take the assessment results as guidelines in searching for appropriate resolutions to institutional and personnel problems. Hulpia et al. (2012) stated that exemplified instructional leadership behaviors which truly affect all the subordinates' works in educational institutions. The study highlights the importance of collaborations from every part of the institutions in managing education qualities. This management goals reach social agreement of a certain society (Tan, 2012). The overall picture of the board with instructional leadership should reflect the management balance in order to create smooth and effective collaborations.

\section{DISCUSSION}

Instructional leadership in this study was based on the concept of Alig-Mielcarek and Hoy (2005). This concept allowed this research work to bridge the research gap of the previous research which used ISL to study communication, training personnel based on feedbacks, and professional development of personnel in educational institutions and their futures. This study framework would allow the work motivation to be set which could lead to the overall positive and effective work processes of personnel in organizations. The findings from this study was to point out that relationship quality or loyalty could be applied to the dual system of private vocational education system in Thailand. 


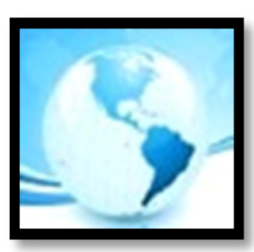

\section{MALAYSIAN ONLINE JOURNAL OF EDUCATIONAL MANAGEMENT (MOJEM)}

The study of leadership and the dual system of private vocational education system in Thailand leads to a clear understanding of how the board should manage human resources in a certain organization. The relationships between variables found through the instructional leadership have shown their impacts on behaviors in the organizations. thus, Instructional leadership could lay the foundation for the board to adjust the organizational systems to reach the final outcome of the learners' academic achievements. With such foundation, the board should not ignore the distribution of well-functioning department. This kind of distribution will lead the better improvement in working qualities and relationships among every part of the institutions

When focusing on the mediator in relationship quality, the relationship between instructional leadership and loyalty was found. It was because of the various dimensions of the relationship quality which could be applied to several contexts or for individual/organizational measurements (Steward, Wu, \& Hartley, 2010). The findings of this study were in the same vein as that of $\mathrm{Ki}$ and Hon (2009)'s research in lights of interactions between individuals both psychologically and economically. The application of relationship quality highlights the extent to which dimensions in relationships should be maximized in order to create or to maintain the positive relationships between leaders and supporters. In addition, such application could help build up the level of confidence among interactants. This research work bridges the gap in the concept of relationship quality although it was done in the context of education. It is to say that any good leadership and management which bring positive work experiences and collaborations would nurture the growth of any educational institutions. Along the same line, Saridakis, Lai, Muñoz Torres, and Gourlay (2018) claimed that, although the social exchange theory and the relationship quality may not be similar. Their outcomes are expected to highlight work of commitment with loyalty that based on the trusted and solid exchanges in social and work contexts are in the same vein.

Many literature reviews suggest that the obstacle that prevents loyalty among the personnel is management in educational institutions. The study of Aas (2016), personnel in educational institutes believe that executives will improve the organization by creating practice guidelines beneficial for the workplace. Although employees will still perform according to expectation rather than just following a leader's commands, which would be considered an over-commitment towards a particular person (Jiang \& Cheng, 2008). Instructional leaders are enabled to interweave teaching and learning processes so that instructors and learners are fully engaged in the processes to gain their developments (Liu \& Hallinger, 2018). Kazak and Polat (2018) claimed that the leaders themselves need to oversee the organizations by putting a more direct emphasis on staff diversity and a more indirect attention on organizational structure which governs work policies and regulations. This will eventually hinder employees' loyalty by accountabilities from leader. Such management relates to institutional businesses which in turn affect parents or learners. The teaching and learning could become problematic because of the unfair distribution of resources to ease the work. The design of the courses could be too complicated that the instructors could not manage them for the programs. The instructors may have been assigned repetitive and burden tasks in terms of academic services and teaching loads to serve the educational institutions' policies as well as rules and regulations of the public sectors. These affect the learners' learning processes when the time is limited. Apart from the management in educational institutions, the dual system that governs the collaboration between educational institutions and corporates may also be considered as another obstacle. The instructors may feel the need to gain more in their professional development. It is to be able to adapt and adjust themselves professionally according to the dynamic of society and the management of the institutional board. The instructors would need to consider long and hard of how to manage the programs they are responsible for. It is to allow the program managements to align with the dual system and with the customized learners' professional goals. All of these managements are diverse in forms and dynamically fluctuate depending on specific contexts and human resources in the educational institutions.

This study points out to the importance of instructional leadership that affects behaviors. Some variables statistically reflect insignificant relationships. Trust was found not to statistically relate to job satisfaction and organizational loyalty. It is possible that trust is dealt with emotions stemmed from interactions and maintaining such interactions (Kramer \& Tyler, 1996). Job satisfaction may in fact be dealt with the board management and not 


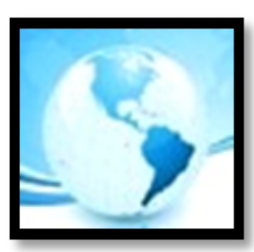

\section{MALAYSIAN ONLINE JOURNAL OF EDUCATIONAL MANAGEMENT (MOJEM)}

with the work content(Nazim, Mikail, \& Engin, 2016). While organizational loyalty is related to individual-oriented expectation towards the organization, trust is focused at the board of management's behaviors and attitudes (Ting \& Yeh, 2014). Consequently, trust was shown not to be related to institutional loyalty.

Instructional leadership and the board are considered as great importance when collaboration in any organization has been set to achieved. The larger the organization, the more thorough communication and work investigation must be in every dimension. It is to allow the work outcomes to be achieved. Moreover, the leaders of organizations must be the ones who are willing to collaborate with other personnel in every dimension. This kind of micro-management allows the leaders to have proper resolutions for the work obstacles. In addition, it could enable the leaders to improve personnel professional qualities through the concept of relationship quality. The relationship quality lays the strong foundation for a sustainability of any educational institution. The findings of this study highlights that although dynamic of contexts keeps present itself, the more importance than the leaders to only proactively manage the institutions should be the stronger the internal management could be set. Despite the fact that instructional leadership may not be the solution towards the leaders' success in management, it is the foundation for every board of educational institutions. The instructional leadership allows the growth professional development in personnel as well as proper management system in educational institutions.

\section{RECOMMENDATIONS}

This research work puts an emphasis on the importance of leadership which enable positive behavioral responses among personnel in private vocational education institutions across Thailand in which they apply the dual system to their institutional systems. The findings of the study suggest that when the mediator is set as Relationship Quality (RQ), the total effect is positive. More specifically, leader loyalty could definitely lead to organizational loyalty. Characteristics of leadership may not be considered as the lone element towards trust building. Continuous support and proper policy plans of educational institutions allow all supporters of the leaders to gain trust and to make strong commitment in working for the institutions and under the board.

Furthermore, this study suggests the measurement of personnel behaviors which enables the development and improvement of educational qualities in educational institutions. Although the dual system that has been applied in private vocational education institutions across Thailand may be flexible when compared to that of the public sectors, they are still governed by the public sectors in terms of rules and regulations of corporate collaborations. To be able to fully achieved the goals in setting up the dual system, the board of management of each educational institution should improve its internal and external communications so that every sector involved thoroughly understands such dual system. The fair distribution of assigning and supporting professional developments for instructors is also another matter of consideration. Such support could be in the form of academic collaborations with other institutions where the instructors could take more professional classes or the learners could receive professional certifications after taking courses or work with the partner institutions. When supporting any professional developments for instructors, such developments should be coming back to the classrooms for the learners. The scope of backup is not only the teaching materials, but also include other teaching elements that must be actively improved.

For any future research study relating to this issue, the focus on leadership could be considered as appropriate towards the future management of the dual system. The system may be applied to public vocational education institutions across Thailand. For such application, any further study should look at the possibility of various forms of leadership with the adaptability potentials towards the objectives of the involved public sectors where one important goal is to strengthen learners' qualifications to fit with the labor market needs and Thailand's economic policies. 


\section{CONCLUSION}

Instructional leadership is well-received and allows a more related positive behaviors to show when focusing on the relationship quality. The more positive the expected personnel behavior is, the more solid plans of educational institutions needed to be set out. According to this study, the relationship quality has a positive effect towards loyalty. It even reflects a more positive effect when considering the universal relationships of each variable in the relationship quality. It could be viewed clearly that in order to encourage a more positive behaviors of the personnel, all behaviors of the personnel should be considered as they are related to their positive behaviors. The finding in regard to loyalty lead to the conclusion that the more the individuals feel positive about the institutions, the more positive behaviors towards work and other matters exhibit.

To apply the findings of this study, the board should work from outside in. That means when the leaders communicate with the external party, they should make any attempt to communicate with their internal staff. The positive characteristics of the instructional leadership, thus, should be ready to give full support and to communicate to their supporters as well as to find proper resolutions to any institutional problems. Such resolutions should reflect the leaders' visions in being able to adapt to the dynamic changes of the system. Overall, the instructional leadership is considered a great fit for the educational context. Its drawbacks may be at the customization level for the leaders to show their capabilities in handling effective management or for the learners' academic outcomes to be achieved as set.

Despite such drawbacks, the use of instructional leadership is considered beneficial in setting up the proper guidelines for educational institution management. Furthermore, it is what every leader should take into serious consideration since the instructional leadership could be effective applied and fit with the dynamic nature of educational policies and any future uncertainties.

Individuals who work in educational institutions must admit that every individual is different. Therefore, the board needs to realize the needs of personnel, create motivations, or be the role model for the institutions. Although the case of dual system, which has recently been applied to Thailand's private vocational education system, allows the flexibility of educational management and customization of learners' educational plans. The board should also consider the needs and problems occurred among administrative personnel, instructors, and learners. The board should investigate and comprehend the matters thoroughly. In addition, it is important that the board has focused on professional trainings which allow all personnel to strengthen their professional and living qualities. This leads to positive relationships between leaders and supporters.

\section{REFERENCE}

Aas, M. (2016). Revisiting instructional and transformational leadership. Journal of Educational Administration, 54(1), 92-110. doi: 10.1108/JEA-08-2014-0105

Aldas-Manzano, J., Ruiz-Mafe, C., Sanz-Blas, S., \& Lassala-Navarré, C. (2011). Internet banking loyalty: evaluating the role of trust, satisfaction, perceived risk and frequency of use. The Service Industries Journal, 31(7), 1165-1190. doi: 10.1080/02642060903433997

Alig-Mielcarek, J. M., \& Hoy, W. K. (2005). Instructional leadership: Its nature, meaning, and influence. In Wayne K. Hoy \& C. Miskel (Eds.), Educational leadership and reform. Greenwich, CN: Infromation Age.

Angle, H. L., \& Perry, J. L. (1981). An empirical assessment of organizational commitment and organizational effectiveness. Administrative Science Quarterly, 26(1), 1-14. doi: 10.2307/2392596

Brislin, R. W. (1980). Translation and content analysis of oral and written material. In H. Triandis \& J. Berry (Eds.), Handbook of cross-cultural psychology : methodology. Boston: Allyn and Bacon.

Buchanan, B. (1974). Building organizational commitment: The socialization of managers in work organizations. Administrative Science Quarterly, 19(4), 533-546. doi: 10.2307/2391809 


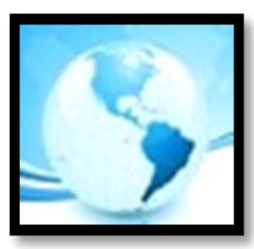

\section{MALAYSIAN ONLINE JOURNAL OF EDUCATIONAL MANAGEMENT (MOJEM)}

Chaudhuri, A., \& Holbrook, M. (2001). The chain of effects from brand trust and brand affect to brand performance: The Role of brand loyalty. Journal of Marketing, 65, 81-93. doi: 10.1509/jmkg.65.2.81.18255

Cohen, A. (2007). Commitment before and after: An evaluation and reconceptualization of organizational commitment. Human Resource Management Review, 17(3), 336-354. doi: 10.1016/j.hrmr.2007.05.001

Dorenkamp, I., \& Ruhle, S. (2018). Work-life conflict, professional commitment, and job satisfaction among academics. The Journal of Higher Education, 90(1), 1-29. doi: 10.1080/00221546.2018.1484644

Dutta, V., \& Sahney, S. (2016). School leadership and its impact on student achievement: The mediating role of school climate and teacher job satisfaction. International Journal of Educational Management, 30(6), 941958. doi: doi:10.1108/IJEM-12-2014-0170

Ennis, M. C., Gong, T., \& Okpozo, A. Z. (2018). Examining the mediating roles of affective and normative commitment in the relationship between transformational leadership practices and turnover intention of government employees. International Journal of Public Administration, 41(3), 203-215. doi: 10.1080/01900692.2016.1256894

Foster, C., Whysall, P., \& Harris, L. (2008). Employee loyalty: an exploration of staff commitment levels towards retailing, the retailer and the store. The International Review of Retail, Distribution and Consumer Research, 18(4), 423-435. doi: 10.1080/09593960802299494

Gregory, J. L. (2017). Trust relationships in schools: supporting or subverting implementation of school-wide initiatives. School Leadership \& Management, 37(1-2), 141-161. doi: 10.1080/13632434.2017.1293639

Hair, J., Black, W., Babin, B., \& Anderson, R. (2009). Multivariate data analysis. Prentice Hall. London.

Hallinger, P., \& Murphy, J. (1985). Assessing the instructional management behavior of principals. The Elementary School Journal, 86(2), 217-247.

Hart, D. W., \& Thompson, J. A. (2007). Untangling employee loyalty: A psychological contract perspective. Business Ethics Quarterly, 17(2), 297-323.

Hong, F.-Y. (2017). Antecedent and consequence of school academic optimism and teachers' academic optimism model. Educational Studies, 43(2), 165-185. doi: 10.1080/03055698.2016.1248902

Houtte, M. V. (2006). Tracking and Teacher satisfaction: Role of study culture and trust. The Journal of Educational Research, 99(4), 247-256. doi: 10.3200/JOER.99.4.247-256

Hoyt, J. E. (2012). Predicting the satisfaction and loyalty of adjunct faculty. The Journal of Continuing Higher Education, 60(3), 132-142. doi: 10.1080/07377363.2013.722417

Hulpia, H., Devos, G., Rosseel, Y., \& Vlerick, P. (2012). Dimensions of distributed leadership and the impact on teachers' organizational commitment: A study in secondary education. Journal of Applied Social Psychology, 42(7), 1745-1784. doi: doi:10.1111/j.1559-1816.2012.00917.x

Hulpia, H., Devos, G., \& Van Keer, H. (2009). The influence of distributed leadership on teachers' organizational commitment: A multilevel approach. The Journal of Educational Research, 103(1), 40-52. doi: $10.1080 / 00220670903231201$

Ilgan, A., Parylo, O., \& Sungu, H. (2015). Predicting teacher job satisfaction based on principals' instructional supervision behaviours: a study of Turkish teachers. Irish Educational Studies, 34(1), 69-88. doi: 10.1080/03323315.2015.1005393

Jiang, D.-Y., \& Cheng, B.-S. (2008). Affect- and role-based loyalty to supervisors in Chinese organizations. Asian Journal of Social Psychology, 11(3), 214-221. doi: doi:10.1111/j.1467-839X.2008.00260.x

Kazak, E., \& Polat, S. (2018). School administrators' instructional leadership behaviors, intergenerational atmosphere, and intergenerational learning in schools. Journal of Intergenerational Relationships, 16(4), 441-462. doi: 10.1080/15350770.2018.1489330

Ki, E.-J., \& Hon, L. (2009). Causal linkages between relationship cultivation strategies and relationship quality outcomes. International Journal of Strategic Communication, 3(4), 242-263. doi: $10.1080 / 15531180903218630$

Klar, H. W. (2012). Fostering department chair instructional leadership capacity: laying the groundwork for distributed instructional leadership. International Journal of Leadership in Education, 15(2), 175-197. doi: 10.1080/13603124.2011.577910

Kont, K.-R., \& Jantson, S. (2014). Organizational commitment in Estonian University Libraries: A review and survey. 


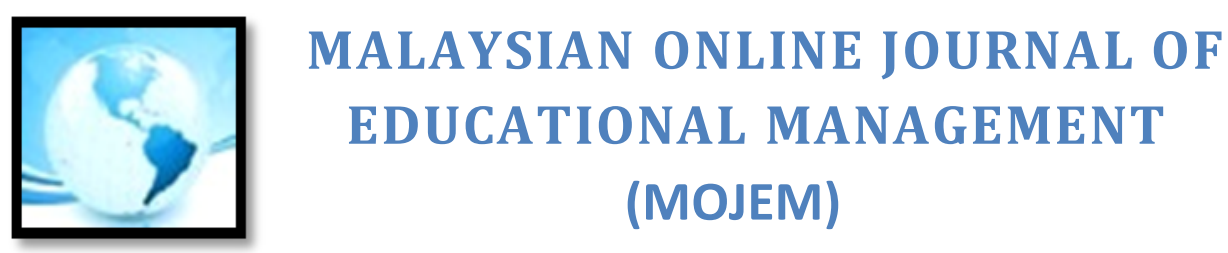

New Review of Academic Librarianship, 20(3), 296-319. doi: 10.1080/13614533.2014.898671

Kramer, R. M., \& Tyler, T. R. (1996). Trust in organizations: Frontiers of theory and research. California: Sage Publications.

Kuhn, S., \& Mostert, P. (2018). Relationship intention and relationship quality as predictors of clothing retail customers' loyalty. The International Review of Retail, Distribution and Consumer Research, 28(2), 206230. doi: 10.1080/09593969.2017.1380067

Lee, S. H., \& Fenich, G. G. (2018). Reconnoitering relationships among value, trust, affect, and loyalty at association events. Journal of Convention \& Event Tourism, 19(3), 313-326. doi: 10.1080/15470148.2018.1470053

Lee, Y. (2016). Relationship quality and its causal link to service value, satisfaction, and word-of-mouth. Services Marketing Quarterly, 37(3), 171-184. doi: 10.1080/15332969.2016.1184541

Leithwood, K. (2016). Department-Head leadership for school improvement. Leadership and Policy in Schools, 15(2), 117-140. doi: 10.1080/15700763.2015.1044538

Lesinger, F., Dagli, G., Gazi, Z. A., Yusoff, S. B., \& Aksal, F. A. (2016). Investigating the relationship between organizational culture, educational leadership and trust in schools. International Journal of Educational Sciences, 15(1-2), 178-185. doi: 10.1080/09751122.2016.11890527

Lindeman, R. H., Merenda, P. F., \& Gold, R. Z. (1980). Introduction to bivariate and multivariate analysis. Dallas Tex: Scott Foresman.

Liu, S., \& Hallinger, P. (2018). Principal instructional leadership, teacher self-efficacy, and teacher professional learning in China: Testing a mediated-effects model. Educational Administration Quarterly, 54(4), 501528. doi: $10.1177 / 0013161 \times 18769048$

Murphy, J. (1990). Principal instructional leadership. In P. W. Thurston \& L. S. Lotto (Eds.), Advances in educational administration : An annual series of analytical essays and critical reviews (Vol. 1). Greenwich, Conn: JAI Press.

Nazim, C., Mikail, Y., \& Engin, K. (2016). Educational leadership and job satisfaction of teachers: a meta-analysis study on the studies published between 2000 and 2016 in Turkey. Eurasian Journal of Educational Research, 26, 255-282 doi: doi:10.14689/ejer.2016.62.13

Ndubisi, N. O., Malhotra, N. K., Ulas, D., \& Ndubisi, G. C. (2012). Examining uncertainty avoidance, relationship quality, and customer loyalty in two cultures. Journal of International Consumer Marketing, 24(5), 320337. doi: 10.1080/08961530.2012.741477

Ng, F. S. D., Nguyen, T. D., Wong, K. S. B., \& Choy, K. W. W. (2015). Instructional leadership practices in Singapore. School Leadership \& Management, 35(4), 388-407. doi: 10.1080/13632434.2015.1010501

Noe, R. A., Hollenbeck, J. R., Gerhart, R., \& Wright, P. M. (2014). Fundamentals of human resource management (5 ed.). Singapore: McGraw-Hill/Irwin.

Northfield, S. (2014). Multi-Dimensional Trust: how beginning principals build trust with their staff during leader succession. International Journal of Leadership in Education, 17(4), 410-441. doi: 10.1080/13603124.2013.825011

Nunnally, J. C. (1967). Psychometric theory. New York, NY, US: McGraw-Hill.

Perin, M. G., Sampaio, C. H., \& Brei, V. A. (2007). Loyalty's antecedents: A Cross-sector study. Latin American Business Review, 8(1), 83-102. doi: 10.1300/J140v08n01_04

Perkins, H. V. (1965). Classroom behavior and underachievement. American Educational Research Journal, 2(1), 112. doi: $10.3102 / 00028312002001001$

Pietsch, M., \& Tulowitzki, P. (2017). Disentangling school leadership and its ties to instructional practices - an empirical comparison of various leadership styles. School Effectiveness and School Improvement, 28(4), 629-649. doi: 10.1080/09243453.2017.1363787

Robinson, S. L. (1996). Trust and breach of the psychological contract. Administrative Science Quarterly, 41(4), 574599. doi: $10.2307 / 2393868$

Rojas-Méndez, J. I., Vasquez-Parraga, A. Z., Kara, A., \& Cerda-Urrutia, A. (2009). Determinants of student loyalty in higher education: A Tested relationship approach in Latin America. Latin American Business Review, 10(1), 21-39. doi: 10.1080/10978520903022089

Saridakis, G., Lai, Y., Muñoz Torres, R. I., \& Gourlay, S. (2018). Exploring the relationship between job satisfaction 


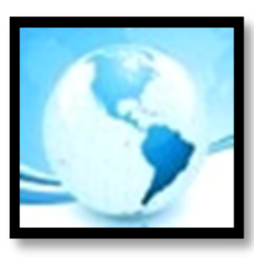

\section{MALAYSIAN ONLINE JOURNAL OF EDUCATIONAL MANAGEMENT (MOJEM)}

and organizational commitment: An instrumental variable approach. The International Journal of Human Resource Management, 1-31. doi: 10.1080/09585192.2017.1423100

Sayadi, Y. (2016). The effect of dimensions of transformational, transactional, and non-leadership on the job satisfaction and organizational commitment of teachers in Iran. Management in Education, 30(2), 57-65. doi: 10.1177/0892020615625363

Shen, J., Leslie, J. M., Spybrook, J. K., \& Ma, X. (2012). Are principal background and school processes related to teacher job satisfaction? A multilevel study using schools and staffing survey 2003-04. American Educational Research Journal, 49(2), 200-230. doi: 10.3102/0002831211419949

Smith, S. C., \& Piele, P. K. (1997). School leadership : Handbook for excellence (3 ed.). Eugene, Or: ERIC Clearinghouse on Educational Management, University of Oregon.

Steward, M. D., Wu, Z., \& Hartley, J. L. (2010). Exploring supply managers' intrapreneurial ability and relationship quality. Journal of Business-to-Business Marketing, 17(2), 127-148. doi: 10.1080/10517120903407857

Tan, C.-Y. (2012). Instructional leadership: Toward a contextualised knowledge creation model. School Leadership \& Management, 32(2), 183-194. doi: 10.1080/13632434.2011.614944

Thobega, M., \& Miller, G. (2003). Relationship of instructional supervision with agriculture teachers' job satisfacation and their intention to remain in the teaching profession. Journal of Agricultural Education, 44, 57-66. doi: 10.5032/jae.2003.04057

Ting, S.-C., \& Yeh, L.-Y. (2014). Teacher loyalty of elementary schools in Taiwan: the contribution of gratitude and relationship quality. School Leadership \& Management, 34(1), 85-101. doi: 10.1080/13632434.2013.813453

Vaughn, W. J., \& Dunn, J. D. (1974). A study of job satisfaction in six university libraries. College and Research Libraries, 35(3), 163-177.

Zhu, Y., \& Akhtar, S. (2014). The mediating effects of cognition-based trust and affect-based trust in transformational leadership's dual processes: Evidence from China. The International Journal of Human Resource Management, 25(20), 2755-2771. doi: 10.1080/09585192.2014.934885 